\title{
PRODUCT QUALITY AND BRAND IMAGE TOWARDS CUSTOMERS' SATISFACTION THROUGH PURCHASE DECISION OF WARDAH COSMETIC PRODUCTS IN SURABAYA
}

\author{
Ernesto Jose Tjahjono \\ Management Department, Unika Widya Mandala University, Indonesia \\ ernesto.tjahjono@yahoo.co.id \\ Lena Ellitan \\ Management Department, Unika Widya Mandala University, Indonesia \\ lena@ukwms.ac.id \\ Yuliasti Ika Handayani \\ Management Department, Unika Widya Mandala University, Indonesia \\ yuliasti@ukwms.ac.id
}

\begin{abstract}
This study aims to determine and examine the effect of product quality on purchasing decisions, the influence of brand image on purchasing decisions, the influence of purchasing decisions on customer satisfaction, the effect of product quality on customer satisfaction through purchasing decisions, and the influence of brand image on customer satisfaction through purchasing decisions. This research is in the form of quantitative research, where the data obtained is primary data obtained through distributing questionnaires to 120 respondents who have made purchases of Wardah cosmetic products. The data obtained were then processed using the Smart PLS software. The results showed that there was a positive and significant relationship between product quality and brand image variables on purchasing decisions, which means that good product quality and good brand image will create purchasing decisions for consumers. Purchase decisions have a positive influence on customer satisfaction. Product quality has a positive and significant effect on customer satisfaction. Brand Image does not significantly influence customer satisfaction. Product quality and brand image have a positive and significant effect on customer satisfaction through purchasing decisions. This shows that consumers will be satisfied with a product when consumers are satisfied with the purchasing decisions made on the product.

Keywords: Product Quality, Brand Image, Purchase Decision, Customers' Satisfaction.
\end{abstract}




\section{INTRODUCTION}

In this millennial era, the business area has been growing rapidly. Its development is followed by the tight competition in some business areas. This competition requires every business to create a different product compared with others especially in cosmetics. Based on the data from the Industrial Ministry, cosmetic industries will be a prosperous business until the next 15 years.

The necessity in creating products is maintaining the quality of the product. It is the main key for each company to run their business. The requirement for a good quality product to be the main criteria for consumers is that it can give more benefits to the consumers. Kotler and Keller (2016) argue that the product quality is the privilege had by a product to generate appropriate and better output as expected by consumers.

Every company which focuses on its product quality, especially for cosmetic companies, certainly will always put an effort on the assurance of product quality by continuously doing quality control checking. The assurance of the production quality generally starts with the materials, production process and even until the final goods. By having the quality control on a product, it aims to give the customers a guaranteed standardization that the prefered product has fulfilled the criterias of giving benefits toward the customers' daily needs. Nowadays cosmetic companies have released high quality local cosmetic products with affordable prices so that the customers may definitely purchase the products.

There are some functions of cosmetics such as lipstick for lips, eye shadow for beautifying eyelids, powder for face, cleansing for face cleaner, and foundation for face. Besides maintaining the product quality, cosmetic companies also have to maintain the brand image of the product itself. Djatmiko and Pradana (2016) explain that brand image is assumed as the description perceived in the customers' minds while thinking about a certain product. It shows that brand image has important roles for a product to remain in customers' minds, and to be considered as a special product different from others so in a consequence the customers may feel more benefits from the product.

Every company with good quality products, brand image, and services will bring influence towards customers' purchase decisions. Djatmiko and Pradana (2016) elaborate that purchase decision is a process of taking decisions including choosing the selected product that will determine the final decision gained from the previous process.

Product quality and brand image are connected with each other because those two influence customers' perception on the products and business (Nikhashemi, et al., 2017). Customers' satisfaction is the main resource for any companies both in goods and services, but at the same time it can be assumed as a counterpoint (Hofacker and Belanche, 2016; Arvidsson and Caliandro, 2016). Customers' satisfaction creates loyalty so that the customers will be loyal to the company, products, and services. 
Companies should understand the importance of customers' satisfaction as it is easier to possess old customers than getting the new ones (Chen et al, 2018). The personality \& characteristics of each customer are surely different thus by having product quality and brand image on purchase decision will reflect the customers' satisfaction in getting the benefits from the chosen products.

From some developed local cosmetic companies in Indonesia, Wardah cosmetic is one of popular local products in Indonesia. Wardah is a company of beauty product manufacturers owned by a spouse named Drs.H. Subakat Had, M.Sc. and Dra. Hj. Nurhayati Subakat, Apt. Wardah has become the first local brand which has the highest sales in Matahari department store and gets the third place of best products from all local and international brands.

Wardah also has the ability to compete with other cosmetic products from various brands. Wardah is able to maintain its existence in the cosmetic industry by achieving various achievements in some categories. By achieving various achievements, it shows the positive response from the customers towards the brand image of Wardah the halal cosmetics.

With its product popularity in Indonesia, there is always the possibility for Wardah cosmetic company to have a chance of becoming the firstocal cosmetic product which is able to compete with international products which are used to be more expensive. The connection between product quality and brand image towards purchase decisions which influence customers' satisfaction make this study conducted on Wardah, a local cosmetic company.

This study aims to investigate the factors influencing customers' purchase decision and satisfaction on Wardah cosmetic products. This study proposes that product quality and brand image become the important factors that influence the customers' purchase decision and satisfaction on Wardah cosmetic products in Surabaya.

Quality is the suitability of the product for its function, the comfort of the product when used, the value of the price paid, sales service, and psychological criteria such as the perceived prestige of consumers. According to Kotler and Keller (2016), product quality is the strength for a product to come up beyond customers' expectations. Tjiptono (2015) explains that product quality describes several characteristics consisting of goods and services, people, process, and environment beyond the expectation. As explained by Tjiptono in Baruna et al (2017) there are some indicators of product quality: 1). Performance, Performance indicates levels of benefits received by the customers from the product considering mainly on the product quality coming with several product varieties; 2). Reliability, It is the product quality captured by customers including the product's package and the cosmetic quality; and 3). Conformity to Specifications, The product should have the standardized characteristics and compositions.

Brand image shows that the name prestige will depend on the individual's interpretation and understanding of the brand about the meaning of the individual's mark, good or bad, attitude or assessment accompanied by the trend of individual Journal of Entrepreneurship \& Business, Vol.2, No. 1. 
behavior towards the brand. Sutopo (2017) argues that brand image becomes people's perception on a brand which represents the association of the brand in the customers' views. In addition, Tjiptono (2015:49) states that brand image is the representation of product's reliability and customers' assurance towards a brand. Likewise, Venessa and Arifin (2017) explain that brand image is a belief coming up in the customers' mind as the comparison with other brands. Aaker and Biel (2009:71) add some indicators creating brand image, those are: 1). Corporate Image, The product has good credibility to its customers; 2). Product Image, The product gives benefits and guarantee to its customers; and 3). User Image, The customers' perception towards the product use in their social status.

According to Kotler and Keller (2016), the taking-decision process in a purchase happens as in the following sequences: recognizing the necessity problems, collecting information, evaluating alternatives, deciding to purchase and response after purchase. The purchase decision is defined as a personal mindset in various choices and determines the decision on a product. Kotler and Armstrong (2014) define purchase decisions as the phases taken by customers who surely intend to buy a good or service. According to Tjiptono (2016: 295), there are five indicators in measuring customers' satisfaction, those are: 1). Quality of the product or service, The product is able to fulfill customers' expectation; 2). Quality of the treatment, Customers feel satisfied with the treatment given by the product; 3 ). Price, Product with an affordable price is able to provide high quality and value for the customers; 4). Emotional factor: The product successfully makes the customers proud of using it and convinced that other people are amazed by them; and 5). Cost and availability, The product is easy to find and doesn't spend much expense for it.

Kotler and Armstrong (2014) define purchase decision as the phases taken by customers who surely intend to buy a good and service. While Schiffman and Kanuk (2010) illustrate purchase decision as a selection between two or more solutions in conducting any purchase, it means when the customer is going to take the decision, there should be some solutions to choose. According to Kotler and Amstrong (2014), there are four indicators in purchase decision as follows: 1). Stability of a product and service, Stability of a product and service is identified from the quality, value, and price that convince the customers in purchasing a product; 2). Habit in buying product and service, The customers' habits in purchasing the product influence purchase decision; 3). Giving a recommendation for others, Customers who feel the benefits from using the product influence the purchase decision; and 4). Conducting repurchase, Once the customers get the satisfaction of a product, it will lead them to repurchase the product.

Purchase decision is the phase for customers determining the choice from several options of products related to their needs. Djumarno, et al., (2017) identify that great product quality will lead to a good purchase decision . Sudarsono, et el.,(2020) in PT. kewpie Indonesia demonstrates that product quality significantly influences purchase decision. In an accordance, there was another research conducted by Sudodo and Hakim (2019) to the customers of Oriflame in Sumbawa regency showing that 
product quality positively \& significantly had impacts on purchase decision. Furthermore, Ernawati's research (2019) done in Bandung revealed that product quality brought positive influence towards purchase decision. Regarding the explanation before, the proposed hypothesis is specified as follow:

H1: Product Quality brings influences towards purchase decision

A strong and popular brand image turns out to be customers' main reference in determining a decision to buy a product, brand image may influence customers' satisfaction and contribute to the future advantages (Cheung et al., 2020). A research implemented in Turkey by Omer et all., (2014) explained that there were influences of brand image towards purchase decision. Another research done by Djatmiko and Pradana (2015) in Malaysia demonstrated that brand image had positive impacts in improving purchase decision. Aaker and Keller (1990) argue that customers' loyalty lies on brand, trust, snf intention in conducting product purchase influenced by brand image. In addition, there was another research done by Agmeka, et al.,(2019) in Indonesia describing that brand image definitely brought influences to customers' purchase decisions especially for the industries in Indonesia. Based on some prior conducted researches, the proposed Hypothesis is specified as follow:

$\mathrm{H} 2$ : Brand Image brings influences towards purchase decision

Customers' satisfaction from a product after having the phases of purchase decision will give positive value for every company to develop their products. Kotler and Keller (2016) define the five phases of purchase activity, those are identifying excitement, finding clarification, evaluating solutions, determining decisions at purchasing, and having response after purchasing. Whenever being in the top-end process, that is having response after purchasing, the customers will evaluate whether their purchases have or haven't been as expected. For the consequence, the response that may follow can be either satisfaction or dissatisfaction. The research conducted by Savitri, et al.,(2016) in Malang illustrated that purchase decisions positively and significantly influenced customers' satisfaction. This was also supported by another research done by Gupron (2020) to Batanghari University students in Jambi that showed purchase decision influenced significantly towards customers' satisfaction. Considering some conducted researches, the proposed hypothesis is specified as follow:

H3: Purchase Decision bring influence towards customers' satisfaction.

By having a good quality for, it will lead the customers to get satisfied with the selected product. The research done by Putra, et al., (2017) to Brawijaya University students majoring in Business Administration indicated that product quality positively and significantly influenced the customers' satisfaction where the higher product quality went, the greater customers' satisfaction the product would get. Furthermore this was also supported by Ghassani and Suryoko (2017) in their research in Semarang showing that product quality influenced positively and 
significantly towards customers' satisfaction. So did with a research by Tombeng, et al., (2019) in Manado. In addition, Sari and Lestari (2019) in their research implemented to the customers of Argo Parahyangan executive train explained that product quality influenced positively and significantly towards customers' satisfaction. Regarding some prior implemented researches, therefore the proposed hypothesis is specified as follow:

H4: Product quality brings influences towards customers' satisfaction.

A research conducted by Yesenia and Siregar (2014) to the customers of KFC in South Tangerang indicated that brand image didn't influence customers' satisfaction. Likewise Kurniawati, et al.,(2019) in their research implemented to Pizza Hut customers in Jember showed that brand image didn't influence significantly the customers' satisfaction. From the mentioned researches thus the proposed hypothesis is specified as follow:

H5: Brand Image doesn't bring influences towards customers' satisfaction

Every company must have the ability to improve their product quality so that their promoted product will be able to give benefits for their customers' needs. According to Kotler and Armstrong (2014), product quality illustrates some characteristics owned by the product which exhibit the capabilities in desire fulfillment and consist of endurance, reliability, accuracy, and simplicity in maintaining other aspects in some products. That statement goes along with the research conducted by Patmawati and Syarif (2020) in Kasablanka city showing that product quality significantly influenced customers' satisfaction. Along with a good product quality, it will arouse satisfaction on the customers through purchase decision. A decision generally is defined as a process of selecting two or more alternative options. The options may include choices of brands, times, distribution, and many else (Schiffman and Kanuk, 2008: 485). Other research in Bojonegoro done by Noor and Utari (2020) also showed that product quality significantly brought impact to customers' satisfaction through purchase decision. Thus considering the research results as mentioned above, the proposed hypothesis is specified as follow:

H6: Product quality brings influences towards customers' satisfaction through purchase decision.

Setiadi (2003: 180) states that brand image represents the form of the overall view of a product which is built from facts and past experience on the product. Brand image on a product is very important especially for its customers because customers think that a product with a good brand image will be able to fulfill the customers' needs. It is supported by the research done by Qomariah and Wibowo (2019) to Herbalife customers that indicated that brand image significantly influenced customers' satisfaction. With the customers satisfaction towards the brand image will lead the customers towards purchase decision. Kotler and Armstrong (2014) define the purchase decision as customers' activities in identifying problems, collecting facts 
about the good or the brand then evaluate the positive result for any solution to solve the root of the problem and finally concern the purchase decision. Other research done by Hartono and Wahyono (2015) also showed that brand image positively and significantly influenced customers' satisfaction through purchase decision. Based on the previous researches, the proposed hypothesis is specified as follow:

H7: Brand Image brings influence towards customers satisfaction through purchase decision.

\section{RESEARCH METHODS}

The approach implemented in this research is a quantitative study method. It employs research data in numbers and being analysed using the statistics (Sugiyono, 2018, p.7). A study which is arranged and designed using hypotheses will examine the causality between variables, those are the influence of product quality and brand image towards customers' satisfaction through purchase decision which implement quantitative approach. And Wardah cosmetic products are determined as the objects of the study. Population for this study is the women in Surabaya city. This study chooses purposive sampling in which the samples are selected from the suitable population related to the purpose and meaning of this study. Characteristics used for the sample consideration are: Women aged around 17-55 years old, and Women who have ever purchased Wardah cosmetic products.

Independent variables in this study are product quality and brand image. Intervening variable for this study is purchase decision. An dependent variable of this study is customers' satisfaction. This study applies an assessment technique of likert scale to conduct variable assessment. Likert scale is the scale used to examine someone or people's behaviour, opinion, and perception about social phenomenon (Sugiyono, 2008, p. 93). Data analysis technique is used to answer problem formulation or examine the formulated hypothesis ( Sugiyono 2015: 331). Data processing in this study uses SEM (Structural Equation Modeling) supported by Smart PLS Software. Smart PLS is conducted by evaluating outer and inner models. Outer model defines how each block of indicator is connected to other latent variables. Inner model illustrates the connection among latent variables based on substantive theory (Ghozali, 2014). The outer model used in validity assessment classified into 2: Convergent Validity and Discriminant Validity. The value of Convergent Validity is the value of loading factor on latent variables with their indicators. If the loading factor value is more than 0,5 , the indicator is considered valid. Meanwhile, the value of Discriminant Validity is used to evaluate indicators with their latent variables. Discriminant Validity assessment on indicator models using Smart PLS Software is done based on cross loading. If a loading factor of an indicator related to its latent variable shows higher value than the loading factor of indicator related to another latent variable, the indicator is considered valid (Abdillah and Jogiyanto, 2009). Reliability Assessment is done to measure the consistency of the instruments. Reliability indicates consistency level, accuracy, and credibility of an instrument in measuring a construct. The reliability assessment for this study is 
implemented based on the Composite Reliability and Cronbach's Alpha values. Reliability of a variable can be figured out using PLS program if Cronbach's Alpha value for each variable is bigger than the decided coefficient of Cronbach's Alpha that is > 0,6 and Composite Reliability is > 0,7 (Sekaran and Bougie, 2016, p. 225).

From the bootstrapping process, a parameter of the statistical test is obtained to predict the causality (Jogiyanto, 2009). The decided Inner model will be evaluated using R-square. R-square value shows how much eksogen variable explains the endogen variable. The closer it is to 1 , the further information independent variables will give to predict dependent variables. Hypothesis assessment is done to identify the significance of each independent variable towards the dependent variable. The criteria of significance assessment in this study is seen from the cutoff by 1.96 (in which $\alpha=5 \%$ ). If every parameter estimate has t value bigger than 1,96 , thus the correlation among variables is considered significant (Ghozali and Faud, 2005:40).

\section{RESULTS \& DISCUSSION}

Product Quality was measured using 4 instruments. The total average value of measurement from the variables of Product Quality was 4,242 and the total average value of Deviation Standard on Product Quality variables was 0,826. The highest average was on the indicator of "I think Wardah cosmetic products are well and safe packaged" by the average of 4,360. Meanwhile the lowest average was on the indicator of "I think Wardah cosmetic products have the SNI standardized composition" by the average of 4,140. Thus from the total average, it could be concluded that participating respondents definitely agreed with the indicators listed in the questionnaire. Those testify that the average respondents feel satisfied with Wardah cosmetic products.

Table 1.

Descriptive Assessment Result

\begin{tabular}{llrrl}
\hline No & Variable & Mean & $\begin{array}{c}\text { Standard } \\
\text { Deviation }\end{array}$ & Information \\
\hline 1. & Product Quality & 4,242 & 0,826 & Strongly agree \\
2. & Brand Image & 4,013 & 0,965 & Agree \\
3. & Customer Satisfaction & 4,300 & 0,802 & Strongly agree \\
4. & Purchase Decision & 4,077 & 0,909 & Agree \\
\hline
\end{tabular}

Brand Image was measured using 3 instruments. The total average value of measurement from the variables of Brand Image was 0,965. The highest average was on the indicator of "I think Wardah cosmetic products give the customers beauty benefits" by the average of 4,170. Meanwhile the lowest average was on the indicator of "I think Wardah cosmetic products are already trusted and popular among society" by the average of 3,730. Thus from the total average, it could be concluded that participating respondents definitely agreed with the indicators listed in the 
questionnaire. Those testify that the average respondents feel satisfied with Wardah cosmetic products.

Customer satisfaction was measured using 4 instruments. The total average value of measurement from the variables of Customers Satisfaction was 4,300 and the total average value of Deviation Standard on Customers Satisfaction variables was 0,802. The highest average was on the indicator of "Wardah cosmetic products are easily found in the nearby store" by the average of 4,650. Meanwhile the lowest average was on the indicator of "I am proud of using Wardah" by the average of 4,020. Thus from the total average, it could be concluded that participating respondents definitely agreed with the indicators listed in the questionnaire. Those testify that the average respondents feel satisfied with Wardah cosmetic products.

Purchase decision was measured using 4 instruments. The total average value of measurement from the variables of Purchase Decision was 4,077 and the total average value of Deviation Standard on Purchase Decision variables was 0,909. The highest average was on the indicator of "I am going to repurchase Wardah cosmetic products because I get satisfied with the products" by an average of 4,250. Meanwhile the lowest average was on the indicator of "It's hard for me to move on other cosmetic products because I am used to purchasing Wardah " by the average of 3,730. Thus from the total average, it could be concluded that participating respondents definitely agreed with the indicators listed in the questionnaire. Those testify that the average respondents feel satisfied with Wardah cosmetic products.

The coefficient of product quality influence on purchase decision was 0,338 with T-value by 3,164 indicated that T-value was more than 1,96. From this measurement, it can be stated that there was significant influence between product quality and purchase decision. It means that the higher the product quality goes, the more purchase decision will be. Based on this result, thus $\mathrm{H} 1$ is accepted.

The coefficient of brand image influence on purchase decision was 0,582 with Tvalue by 5,797 indicated that T-value was more than 1,96. From this measurement, it can be stated that there was significant influence between brand image and purchase decision. It means that the better brand image is, the higher purchase decision will be. Based on this result, thus $\mathrm{H} 2$ is accepted.

The coefficient of purchase decision influence on customers' satisfaction was 0,223 with $\mathrm{T}$-value by 2,168 indicated that $\mathrm{T}$-value was more than 1,96 . From this measurement, it can be stated that there was significant influence between purchase decision and customers' satisfaction. It means that the higher purchase decision goes, the better customers' satisfaction will be. Based on this result, thus $\mathrm{H} 3$ is accepted.

The coefficient of product quality influence on customers' satisfaction was 0,478 with $\mathrm{T}$-value by 4,368 indicated that $\mathrm{T}$-value was more than 1,96. From this measurement, it can be stated that there was significant influence between product quality and customers' satisfaction. It means that the higher product quality goes, the more customers' satisfaction will be. Based on this result, thus $\mathrm{H} 4$ is accepted.

The coefficient of brand image influence on customers' satisfaction was 0,202 with $\mathrm{T}$-value by 1,702 indicating that $\mathrm{T}$-value was less than 1,96. From this 
measurement, it can be stated that there wasn't significant influence between brand image and customers' satisfaction. Based on this result, thus H5 is not accepted.

The coefficient of product quality influence on customers' satisfaction through purchase decision was $-0,262$ with T-value by 2,619 indicating that T-value was more than 1,96. From this measurement, it can be stated that there was significant influence between product quality and customers' satisfaction through purchase decision. It means that the higher the product quality goes, the better customers' satisfaction will be through purchase decision. Based on this result, thus H6 is accepted.

Table 2.

Recapitulation of the Relationship between Variables

\begin{tabular}{|l|r|r|r|l|}
\hline Variable Relationship & $\begin{array}{l}\text { Original } \\
\text { Sample }\end{array}$ & $\begin{array}{l}\text { t- } \\
\text { value }\end{array}$ & $\begin{array}{l}\text { Cut } \\
\text { off }\end{array}$ & Information \\
\hline $\begin{array}{l}\text { Product Quality } \rightarrow \text { Purchase } \\
\text { Decision }\end{array}$ & 0.338 & 3.164 & $>1.96$ & Significant \\
\hline $\begin{array}{l}\text { Brand Image } \rightarrow \text { Purchase } \\
\text { Decision }\end{array}$ & 0.582 & 5.797 & $>1.96$ & Significant \\
\hline $\begin{array}{l}\text { Purchase Decision } \rightarrow \\
\text { Customer Satisfaction }\end{array}$ & 0.223 & 2.168 & $>1.96$ & Significant \\
\hline $\begin{array}{l}\text { Product Quality } \rightarrow \text { Customer } \\
\text { Satisfaction }\end{array}$ & 0.478 & 4.368 & $>1.96$ & Significant \\
\hline $\begin{array}{l}\text { Brand Image } \rightarrow \text { Customer } \\
\text { Satisfaction }\end{array}$ & 0.202 & 1.702 & $>1.96$ & Not Significant \\
\hline $\begin{array}{l}\text { Product Quality } \rightarrow \text { Purchase } \\
\text { Decision } \rightarrow \text { Customer } \\
\text { Satisfaction }\end{array}$ & -0.262 & 2.619 & $>1.96$ & Significant \\
\hline $\begin{array}{l}\text { Brand Image } \rightarrow \text { Purchase } \\
\text { Decision } \rightarrow \text { Customer } \\
\text { Satisfaction }\end{array}$ & 0.272 & 2.781 & $>1.96$ & Significant \\
\hline
\end{tabular}

The coefficient of brand image influence on customers' satisfaction through purchase decision was 0,272 with T-value by 2,781 indicated that T-value was more than 1,96. From this measurement, it can be stated that there was significant influence between brand image and customers' satisfaction through purchase decision. It means that the better the brand image is, the more customers' satisfaction will be through purchase decision. Based on this result, thus $\mathrm{H} 7$ is accepted.

This study analyzes the influences of product quality and brand image towards customers' satisfaction through purchase decision on Wardah cosmetic products in Surabaya. This study was implemented using Structural Equation Modeling-Partial Least Square (SRM-PLS). The results of this study was concluded as follow: Product Quality (X1) has positive and significant influence towards Purchase Decision (Z), it proves that Product Quality increases Purchase Decision influence on Wardah cosmetic products in Surabaya. Brand Image (X2) has positive and significant 
influence towards Customers' Satisfaction (Y), it proves that Brand Image increases Purchase Decision on Wardah cosmetic products in Surabaya. Purchase Decision (Z) has positive and significant influence towards Customers' Satisfaction (Y), it proves that Purchase Decision increases the influence of Customers' Satisfaction on Wardah cosmetic products in Surabaya. Product Quality (X1) has positive and significant influence towards Customers' Satisfaction (Y), it proves that Product Quality increases Customers' Satisfaction on Wardah cosmetic products in Surabaya. Brand Image (X2) has no significant influence towards Customers' Satisfaction (Y), it proves that Brand Image doubtfully increases Customers' Satisfaction on Wardah cosmetic products in Surabaya.Product Quality (X1) has positive and significant influence towards Customers' Satisfaction through Purchase Decision, it proves that Product Quality increases Customers' Satisfaction through Purchase Decision on Wardah cosmetic products in Surabaya. Brand Image (X2) has positive and significant influence towards Customers' Satisfaction through Purchase Decision, it proves that Brand Image increases Customers' Satisfaction through Purchase Decision on Wardah cosmetic products in Surabaya.

\section{CONCLUSION}

The results of this study can be the reference for similar researches which use the theories and concepts of product quality, brand image, purchase decision, and customers' satisfaction. For next researchers, it will be useful to have deeper analysis by adding other variables which may influence customers' satisfaction, such as price as it influences customers' satisfaction. Moreover, the next research may also add more respondents by expanding the distribution area to get more accurate results.

It can be seen that the lowest respondents' evaluation was on the Product Quality variable with the statement of "I think Wardah cosmetic products have proper composition as in SNI standard". Therefore the development of Wardah cosmetic products can be done in several ways such as doing quality control so that the products should have the right composition as in SNI standard so they will be safe for customers. From the packaging, the products have to be more creative related to the market targets which are women, so that the package will interest more female customers. It can be seen that the lowest respondents' evaluation was on Brand Image variables with the statement of "I think Wardah cosmetic products have been trusted and popular in society". Therefore the development of Wardah cosmetic products can be done using some approaches such as holding beauty seminars, expanding the market targets, utilizing some social media platforms like beauty endorsers and influencers in introducing and promoting the products through Youtube, Instagram, Facebook, Tok Tok and many others. By doing so, it can help build a positive brand image on the customers. It can be seen that the lowest respondents' evaluation was on Customers' Satisfaction variable with the statement if "I am proud of using Wardah ". Therefore the development of Customers' satisfaction on Wardah cosmetic products can be done by taking surveys on Wardah cosmetic customers to know and evaluate 
the products' weaknesses, increase the brand image through social media by hiring influencers and endorsers so that the products will be known as good and high quality local products. It can be seen that the lowest respondents' evaluation was on Purchase Decision variable with the statement if "IIt's hard for me to move on other products because I am used to purchasing Wardah cosmetic products". Therefore the development of purchase decision can be done by increasing product quality, brand image, maintaining affordable price, available facilities to lead customers to make purchase decision.

Based on the research that has been done, the researcher provides academic advice to further researchers, namely that the results of this study can be a reference for similar tasks that use theories and concepts about product quality, brand image, purchase decisions, and consumer satisfaction. Suggestions for the following researchers are to examine more deeply by adding several other variables that can affect customer satisfaction. Like price because the price can affect customer satisfaction. The following researchers can also increase the number of respondents so that the results obtained are most accurate. Management of the quality of cosmetic products shows that improving Wardah's cosmetic products' quality can be done in various ways. It means conducting quality control where the product has a composition and standardization according to SNI so that it is safe for use by consumers and in terms of product packaging can be more varied because market segmentation is women so that pacakaging can be made more attractive to female consumers. Those who manage the brand image of Wardah cosmetic products can see from the lowest respondents' assessment that the brand image variable lies in the statement, "I feel Wardah's cosmetic products are trusted and known by the public." Enhancement of Wardah's cosmetic brand image by taking several approaches such as holding beauty seminars, expanding market segmentation to be better known by the public, utilizing social media platforms such as beauty endorsers and influencers in introducing and promoting products through social media. Such as Youtube, Instagram, Facebook, TikTok, and other social media so that it indirectly teaches and builds a positive brand image in the minds of consumers.

\section{REFERENCES}

Aaker, David, A., dan Alexander, L. Biel. (2009). Brand equity and advertising: advertising role in building strong brand. Lawrence Erlbaum Associates, Inc., Hillsdale.

Abdillah, W., dan Jogiyanto, H.M. (2009). Konsep dan aplikasi PLS (Partial Least Square). Yogyakarta: BPFE.

Agmeka, Wathoni, dan Santoso (2019). The influence of discount framing towards brand reputation and brand image on purchase intention and Actual Behaviour in e-commerce. Procedia Computer Science, 161, 851-858.

Arvidsson, A., dan Caliandro, A. (2016). Brand public. Journal of Consumer Research, 42 (5), 727-748. 
Baruna H. B., Shilvana H., dan Hapzi A. (2017). The influence of quality products, price, promotion, and location to product pur- chase decision on Nitchi at PT. Jaya Swa- rasa Agung in Central Jakarta. Saudi Journal of Business and Management Studies, 2(4), 433-445.

Chen, T., Drennan, J., Andrews, L., dan Hollebeek, L.D. (2018). User experience sharing: understanding customer initiation of value co-creation in online communities. European Journal of Marketing, 52 (5), 1154-1184.

Cheung, M.L., Pires, G. dan Rosenberger, P.J. III (2020). The influence of perceived social media marketing elements on consumer brand engagement and brand knowledge. Asia Pacific Journal of Marketing and Logistics, 32(3), 695-720.

Djatmiko, T. dan Pradana, R. (2016). Brand im- age and product price; its impact for Samsung smartphone purchasing decision. Procedia Social and Behavioral Sciences, 219, 221- 227.

Djumarno, Sjafar, O., dan Djamaluddin, S. (2017). The effect of brand image, product quality, and relationship marketing on customer satisfaction and loyalty. International Journal of Business Marketing and Management, 2(10), 24564559.

Ernawati, D. (2019). Pengaruh kualitas produk, inovasi produk dan promosi terhadap keputusan pembelian produk Hi Jack Sandals Bandung. Jurnal Wawasan Manajemen, 7(1), 17-32.

Ghassani, M.T. dan S. Suryoko. (2017). Pengaruh kualitas produk dan harga terhadap minat beli ulang Bandeng Juwana vaccum melalui kepuasan konsumen sebagai variabel intervening (studi kasus pada pelanggan PT Bandeng Juwana El- rina Semarang). Diponegoro Journal of Social and Political Science, 6(4), 1-8.

Ghozali, I. dan Fuad. (2005). Structural Equation Modeling: Teori, konsep dan aplikasi dengan program Lisrel 8.54. Semarang: Universitas Diponegoro.

Gupron, G. (2020). Analisis kepuasan konsumen melalui e-service quality terhadap keputusan pembelian daring di aplikasi BUKALAPAK.COM (studi pada mahasiswa Universitas Batanghari Jambi). Jurnal Manajemen Pendidikan dan Ilmu Sosial, 1(1), 337-348.

Hartono, A., dan Wahyono, W. (2015). Pengaruh citra merek dan kualitas terhadap kepuasan konsumen melalui keputusan pembelian sebagai variabel intervening. Management Analysis Journal, 4(2), 153-162.

Hofacker, C.F., dan Belanche, D. (2016). Eight social media challenges for marketing managers. Spanish Journal of Marketing ESIC, 20 (2), 73-80.

Jogiyanto. (2009). Konsep dan aplikasi PLS untuk penelitian empiris. Yogyakarta: Penerbit BPFE.

Kotler, P., and Amstrong, G, (2014), Principles of Marketing, 12th Edition,Jilid 1 Jakarta : Erlangga.

Kotler, P., and Keller, K.L. (2016). Manajemen pemasaran (edisi ke-12). Jakarta: PT Indeks. 
Kurniawati, T., Irawan, B., dan Prasodjo, A. (2019). Analisis pengaruh kualitas pelayanan, harga, dan brand image terhadap kepuasan konsumen restoran Pizza Hut cabang Jember. e-Journal Ekonomi Bisnis dan Akuntansi, 6(2), 147-151.

Nikhashemi, S. R., Valaei, N., \& Tarofder, A. K. (2017). Does Brand Personality and Perceived Product Quality Play a Major Role in Mobile Phone Consumers' Switching Behaviour?, Global Business Review, 18(3), 1-20.

Noor, F., dan Utari, W. (2020). Pengaruh kualitas produk, persepsi harga citra merek ter- hadap keputusan pembelian serta dampaknya terhadap kepuasan konsumen (studi pada konsumen produk PT. Salim Ivomas Pratama Kecamatan Bojonegoro Kabupaten Bojoneogoro). Jurnal Mitra Manajemen, 4(4), 581-594.

Patmawati, N. S., dan Syarif, R. (2020). Pengaruh harga, citra merek dan kualitas produk terhadap kepuasan konsumen Emina di mall Kota Kasablanka. IKRAITH EKONOMIKA, 3(3), 73-83.

Putra, G.P., Z. Arifin dan Sunarti. (2017). Pengaruh kualitas produk terhadap keputusan pembelian dan dampaknya terhadap kepuasan konsumen (survei pada mahasiswa administrasi bisnis fakultas Ilmu Administrasi angkatan 2013 dan 2014 Universitas Brawijaya yang melakukan pem- belian paket data kampus). Jurnal Administrasi Bisnis, 48(1), 124-131.

Qomariah, N., dan Wibowo, Y. G. (2019). Pengaruh brand image, kepercayaan, dan nilai pelanggan terhadap kepuasan pelanggan Herbalife. Jurnal Manajemen dan Bisnis Indonesia, 5(2): 300-312.

Sari, M. R., dan Lestari, R. (2019). Pengaruh persepsi harga, kualitas pelayanan dan kualitas produk terhadap kepuasan dan dampaknya pada minat pembelian ulang konsumen kereta api kelas eksekutif Argo Parahyangan. Oikonomia: Jurnal Manajemen, 15(1), 30-44.

Savitri, M. H., Suhariyono, S., dan Kusumawati,(2016). Pengaruh kualitas produk hijau dan harga premium terhadap keputusan pembelian dan kepuasan konsumen survei pada konsumen Tupperware di distributor resmi PT Adicitra Prima Kencana Malang). Jurnal Administrasi Bisnis, 40(2): 7-16.

Schiffman, L. G., \& Kanuk, L. L.(2010). Consumer behavior. United State of America:Pearson Education.

Sekaran, U. \& Bougie, R. (2016). Research methods for business a skill building approarch (edisi ke-7). United Kingdom.

Sudarsono, A., Nelsi, M., dan Hasanudin. (2020). Pengaruh kualitas produk terhadap pembelian Kewpie salad dressing pada PT. Kewpie Indonesia. Jurnal Ekonomi Efektif, 3(1), 7-14.

Sudodo, Y., dan Hakim, L. (2019). Pengaruh gaya hidup, harga, dan kualitas produk terhadap keputusan pembelian kosmetik Oriflame. Jurnal Manajemen dan Bisnis, 2(1).

Sugiyono. (2016). Metode penelitian kuantitatif, kualitatif, dan R\&D. Bandung: Alfabeta.

Sutopo, T. W. (2017). Analisis pengaruh kualitas produk dan citra merek terhadap loyalitas pelanggan melalui kepuasan pelang- gan sebagai variabel intervening 
(studi pada pelanggan air minum dalam kemasan club di Semarang). Diponegoro Journal of Management, 6(4), 1-15.

Tjiptono, F. (2015). Brand management \& strategy. Yogyakarta: Andi.

Tjiptono, F. (2016). Service quality and satisfaction. Yogyakarta: Andi.

Tombeng, B., Roring, F., dan Rumokoy, F. S. (2019). Pengaruh kualitas pelayanan, harga dan kualitas produk terhadap kepuasan konsumen pada rumah makan Raja Oci Manado. Jurnal EMBA: Jurnal Riset Ekonomi Manajemen Bisnis dan Akuntansi, 7(1), 891-900.

Venessa, I., dan Arifin, Z. (2017). Pengaruh citra merek (brand image) dan harga terhadap keputusan pembelian konsumen. Jurnal Administrasi Bisnis, 51(1), 4448.

Yesenia, Y., dan Siregar, E. H. (2014). Pengaruh kualitas layanan dan produk terhadap kepuasan serta loyalitas pelanggan KFC di Tangerang Selatan. Jurnal Manajemen dan Organisasi, 5(3), 183-199. 